\title{
EFEKTIVITAS PENAMBAHAN TEPUNG DAUN INDIGOFERA DALAM RANSUM TERHADAP PERFORMA AYAM RAS PEDAGING
}

\section{Effectiveness of the Rate of Addition of Indigofera Flour In the Ration On the Performance of Broiler}

\author{
M.A. Fitrah ${ }^{1}$, Purwanta ${ }^{2}$, dan Sumang ${ }^{2}$ \\ ${ }^{1}$ Program Studi Penyuluhan Peternakan, Sekolah Tinggi Penyuluhan Pertanian Gowa \\ ${ }^{2}$ Jurusan Peternakan, Sekolah Tinggi Penyuluhan Pertanian Gowa \\ e-mail: akbarparawangsa8@gmail.com
}

Received: 15 Desember 2019; Accepted: 11 Maret 2020; Published: 30 Juni 2020

\begin{abstract}
ABSTRAK
Kajian ini bertujuan untuk mengetahui efektivitas tingkat penambahan tepung daun indigofera dalam ransum terhadap performa ayam broiler. Pelaksanaan kajian di Kampus STPP Gowa dan penyuluhan di Desa Pallangga Kecamatan Pallangga Kabupaten Gowa. Metode penelitian menggunakan Rancangan Acak Lengkap (RAL) dengan 4 perlakuan dan 4 ulangan dimana setiap perlakuan terdiri dari 4 ekor ayam broiler. Susunan ransum kajian dengan masing-masing taraf penambahan tepung daun indigofera yaitu P0 (control), P1 (5\%), P2 (10\%), P3 (15\%). Data dikumpulkan melalui pengamatan langsung terhadap kajian, wawancara dan kuesioner. Variabel yang diamati konsumsi ransum, pertambahan bobot badan dan konversi ransum. Hasil penelitian menunjukkan bahwa konsumsi ransum tidak berbeda nyata antara P0, P1, P2 dan P3, pertambahan bobot berbeda nyata antara P0, P1, P2 dan P3, dan konversi ransum berbeda nyata antara P0, P2 dan P3, tetapi tidak berbeda nyata dengan P1 sehingga direkomendasikan P1 untuk diterapkan. Hasil penyuluhan di kelompok tani Tompo Gammang mendapat respon positif. Perubahan pengetahuan diperoleh nilai 100 (26,7\%), keterampilan $111(29,6 \%)$ dan sikap 118 (31,5\%), dengan demikian penyuluhan dikategorikan cukup efektif.
\end{abstract}

Kata kunci: Indigofera, performa, ayam ras pedaging

\begin{abstract}
This study aims to determine the effectiveness of the rate of addition of indigofera flour in the ration on the performance of broiler chickens. Implementation of the study at Gowa STPP Campus and counseling in Pallangga Village, Pallangga District, Gowa District. The research method used Randomized Complete Design (RAL) with 4 treatments and 4 replications where each treatment consisted of 4 broiler chickens. The composition of study ration with each level of addition of indigofera powder (PO (control), P1 (5\%), P2 (10\%), P3 (15\%). Data were collected through direct observation of studies, interviews and questionnaires. The variables observed in ration consumption, body weight gain and ration conversion. The results showed that ration consumption did not differ significantly between $P 0, P 1, P 2$ and $P 3$, the weight gain was significantly different between $P 0, P 1, P 2$ and $P 3$, and the conversion of rations differed significantly between $P 0, P 2$ and $P 3$, but not significantly different from $P 1$ so it is recommended $P 1$ to be applied. The outreach results in the Tompo Gammang farmer group received a positive response. Knowledge change was obtained by 100 (26,7\%), skill 111 (29,6\%) and attitude 118 (31,5\%), thus counseling was categorized quite effective.
\end{abstract}

Keywords: Indigofera, performance, broiler 


\section{PENDAHULUAN}

Peternakan di Indonesia saat ini sudah berkembang sangat pesat, seiring dengan kesadaran dari masyarakat akan pentingnya kebutuhan gizi terutama protein hewani berupa daging. Kebutuhan daging di Indonesia relatif semakin meningkat. Untuk memenuhi kebutuhan ini maka pengembangan ternak unggas menjadi sangat penting, salah satunya ayam broiler sebagai salah satu penyedia daging yang relatif murah dan ekonomis.

Broiler adalah ayam ras yang sengaja dibibitkan dan dikembangkan untuk menghasilkan daging yang cepat, dibandingkan dengan daging unggas lainnya. Pertumbuhan broiler yang cepat karena ransum yang disediakan tersedia zat-zat makanan yang diperlukan. Kinerja broiler dipengaruhi oleh konsumsi pakan, pertambahan berat badan, dan konversi pakan.

Salah satu bahan pakan yang berpotensi sebagai bahan pakan sumber protein yaitu daun Indigofera sp. Tanaman Indigofera sp. memiliki produktivitas yang tinggi dan kandungan nutrien yang cukup baik, terutama kandungan proteinnya yang tinggi. Palupi et al. (2014) menyatakan tepung pucuk indigofera berpotensi untuk dimanfaatkan sebagai bahan pakan sumber protein. Penggunaan tepung pucuk Indigoferra Zollingeriana sebanyak 5.9\%, 11, $8 \%$ dan $17,74 \%$ tidak menggangu kesehatan ayam broiler yang ditunjukkan dengan jumlah profil darah ayam broiler masih berada dikisaran normal untuk unggas kecuali leukosit dan eusinofil. Hal ini membuktikan bahwa tepung pucuk Indigoferra Zollingeriana dapat digunakan sebagai bahan pakan sumber protein bagi ayam broiler tanpa mengganggu kesehatan ayam (Melia, 2017).

\section{METODE PENELITIAN}

\section{Bahan dan alat}

Alat yang digunakan dalam kegiatan KIPA adalah kantong plastik, ayakan, tempat pakan, tempat minum, ember, gelas ukur, karung, timbangan elektrik, thermometer, kalkulator, pisau, penggiling tepung, alat tulis menulis, dan kamera. Alat kegiatan penyuluhan adalah benda sesungguhnya dan LCD. Bahan yang digunakan dalam kajian adalah tepung daun indigofera, ransum, air dan DOC ayam broiler, sedangkan bahan kegiatan penyuluhan yang digunakan adalah leaflet.

\section{Metode Pelaksanaan}

1. Pembuatan tepung daun indigofera

Tepung daun indigofera berasal dari daun indigofera yang diambil di lahan hijauan makanan ternak STPP Gowa kemudian dijemur hingga kering. Daun indigofera kemudian digiling hingga halus, selanjutnya diayak menjadi tepung daun indigofera. Berikut skema pembuatan tepung daun indigofera.

2. Pemeliharaan

Pemeliharaan dilakukan di kandang ternak unggas STPP Gowa menggunakan petakpetak kandang yang telah diacak. Pemeliharaan DOC hingga umur 2 minggu dilakukan dengan pemberian pakan secara adlibitum tanpa perlakuan, Setelah ayam berumur 2 minggu baru diberikan perlakuan P0 (control), P1 (5\% tepung daun indigofera), P2 (10\% tepung daun indigofera), P3 (15\% tepung daun indigofera).

\section{Analisis Data}

Analisis data menggunakan Rancangan Acak Lengkap (RAL) (Gasperz, 1991) dengan 4 perlakuan dan 4 ulangan dimana setiap unit percobaan terdiri dari 4 ekor ayam. Parameter yang diamati adalah konsumsi pakan, pertambahan bobot badan dan konversi ransum.

$$
\text { Evaluasi penyuluhan diukur }
$$
menggunakan kuesioner dengan 15 pertanyaan. Metode yang digunakan untuk mengetahui tingkat pengetahuan, keterampilan dan sikap adalah dengan menggunakan skala Likert, kemudian skala nilai tersebut diolah dan ditabulasi dengan menggunakan garis Continuum (Padmowihardjo, 2002). Adapun efektifitas penyuluhan dapat dihitung dengan menggunakan rumus Ginting (1991).

\section{HASIL DAN PEMBAHASAN}

\section{Konsumsi Ransum}

Berdasarkan data rataan konsumsi ransum pada tabel 1, terlihat bahwa pemberian tepung daun indigofera dengan persentase yang berbeda memberikan pengaruh tidak berbeda nyata $(\mathrm{P}>0,05)$ terhadap konsumsi ransum broiler. Hal ini diakibatkan oleh bentuk ransum 
perlakuan berbentuk tepung sehingga sulit dikonsumsi oleh ayam. Berbeda dengan perlakuan tanpa tepung daun indigofera yang cenderung mampu dikonsumsi dengan baik oleh ayam. Sejalan dengan pendapat Parakassi (1990) bahwa konsumsi pakan dipengaruhi oleh bentuk pakan. Pemberian pakan dalam bentuk pellet dapat meningkatkan konsumsi pakan.

Besar konsumsi ransum akan berpengaruh pada jumlah zat nutrisi yang dikonsumsi. Faktor-faktor yang mempengaruhi konsumsi ransum antara lain umur ternak, aktivitas, bangsa ayam dan suhu lingkungan. Fadilah (2005) menambahkan bahwa salah satu yang mempengaruhi besar kecilnya pertambahan bobot badan ayam pedaging adalah konsumsi pakan dan terpenuhinya kebutuhan zat makanan ayam pedaging, maka konsumsi pakan seharusnya memiliki korelasi positif dengan pertambahan bobot badan.

Tabel 1. Rataan konsumsi ransum, pertambahan bobot badan dan konversi ransum ayam broiler dengan penambahan berbagai tingkatan jumlah tepung daun indigofera.

\begin{tabular}{clcccc}
\hline \multirow{2}{*}{ No } & \multirow{2}{*}{ Parameter } & \multicolumn{4}{c}{ Perlakuan } \\
\cline { 3 - 5 } & & P0 & P1 & P2 & P3 \\
\hline 1 & Konsumsi ransum & $1481.25^{\mathrm{a}}$ & $1434.75^{\mathrm{a}}$ & $1392.5^{\mathrm{a}}$ & $1409.25^{\mathrm{a}}$ \\
2 & Pertambahan bobot badan & $1438.5^{\mathrm{a}}$ & $1326.75^{\mathrm{b}}$ & $1231.25^{\mathrm{bc}}$ & $1155.5^{\mathrm{c}}$ \\
3 & Konversi ransum & $1.0^{\mathrm{a}}$ & $1.1^{\mathrm{ab}}$ & $1.1^{\mathrm{b}}$ & $1.2^{\mathrm{c}}$ \\
\hline abc: superskrip pada baris yang sama menunjukkan berbeda nyata $(\mathrm{P}<0,05)$ & & &
\end{tabular}

\section{Pertambahan Bobot Badan}

Berdasarkan hasil analisis ragam, menunjukkan bahwa perlakuan berbeda nyata $(\mathrm{P}<0,05)$ terhadap bobot badan ayam broiler. Setelah diuji lanjut Duncan P0, P1, P2 dan P3 terjadi perbedaan nyata $(\mathrm{P}<0,05)$ tetapi $\mathrm{P} 1$ tidak berbeda nyata $(\mathrm{P}<0,05)$ terhadap $\mathrm{P} 2$, dan $\mathrm{P} 2$ tidak berbeda nyata $(\mathrm{P}<0,05)$ terhadap $\mathrm{P} 3$.

Menurunnya bobot badan ayam dengan semakin besar pemberian tepung daun indigofera diduga karena serat kasarnya yang tinggi. Pada perlakuan P3 kandungan serat kasarnya yaitu $7,85 \%$, sementara unggas masih mentolerir hingga 5\% (Anggorodi, 1985). Menurut Sofjan dan Surisdiarto (2003) bahwa serat kasar yang tinggi di dalam ransum mengakibatkan daya cerna pakan menurun. Menurunnya daya cerana mengakibatkan rendahnya nutrisi yang terserap oleh saluran pencernaan ternak. Menurut Siregar (1980), bahwa pertambahan bobot badan dipengaruhi oleh jumlah ransum yang dikonsumsi, semakin tinggi tingkat konsumsi ransum, semakin tinggi pula pertambahan bobot badan yang dihasilkan dan sebaliknya semakin rendah konsumsi maka semakin rendah pula pertambahan bobot badan.

\section{Konversi Ransum}

Berdasarkan tabel 1 diketahui bahwa konversi ransum kanjian $\mathrm{P} 0$, berbeda nyata dengan P2 dan P3 tetapi tidak berbeda nyata dengan P1. Nilai P0 memang lebih besar di banding dengan perlakuan lainnya, tetapi tidak berbeda nyata dengan P1. Artinya bahwa pada perlakuan P1 masih bisa dikatakan layak diterapkan sebagai ransum ayam broiler.

Tingginya nilai konversi ransum dengan perlakuan penambahan tepung daun indigofera diakibatkan oleh semakin menurunnya jumlah ransum yang dikonsumsi oleh ternak. Hal ini sesuai dengan pendapat Anggorodi (1980), menyatakan bahwa nilai konversi ransum dapat dipenuhi oleh beberapa faktor, diantaranya adalah suhu lingkungan, laju perjalanan ransum melalui alat pencernaan, bentuk fisik, dan konsumsi ransum. Hal ini di dukung oleh Wiradisapstra (1986), bahwa nilai suatu ransum selain ditentukan oleh nilai konsumsi ransum dan tingkat pertumbuhan bobot badan juga ditentukan oleh tingkat konversi ransum, dimana konversi ransum menggambarkan banyaknya jumlah ransum yang digunakan untuk pertumbuhan ayam broiler.

\section{Kelayakan usaha}

Berdasarkan analisis $\mathrm{R} / \mathrm{C}$ ratio pada tabel 2, diketahui dalam kapasitas pemeliharaan 100 ekor ayam broiler dengan perlakuan subtitusi $5 \%$ pakan menggunakan tepung daun indigofera didapatkan hasil 1,08. Artinya bahwa setiap pengeluaran 1 rupiah maka akan didapatkan 1,08 rupiah. Kesimpulannya bahwa 
pemeliharaan ayam menggunakan tepung daun indigofera masih layak digunakan berdasarkan teori bahwa $\mathrm{R} / \mathrm{C}$ ratio > 1 = layak. Peningkatan kapasitas pemeliharaan ayam broiler tentu akan lebih baik sehingga keuntungan bisa lebih besar.

Tabel 2. Analisis R/C ratio penggunaan tepung daun indigofera taraf 5\%

\begin{tabular}{lll}
\hline \multicolumn{1}{c}{ Uraian } & \multicolumn{1}{c}{$\begin{array}{c}\text { Harga satuan } \\
(\mathrm{Rp})\end{array}$} & $\begin{array}{c}\text { Harga total } \\
(\mathrm{Rp})\end{array}$ \\
\hline BIAYA & & 600.000 \\
\hline Ayam broiler 100 ekor & 6000 & 250.000 \\
Sewa kandang 1 periode & 250.000 & 250.000 \\
Sewa peralatan 1 periode & 250.000 & 2.052 .000 \\
Pakan konsentrat 270 kg (3 kg/ekor) & 7600 & 75.000 \\
Tepung daun indigofera & 5.000 & 3.227 .000 \\
Total & & 3.500 .000 \\
\hline PEMASUKAN & & \\
Penjualan ayam broiler 100 ekor & 35.000 & 273.000 \\
PENDAPATAN & & 1,08 \\
Pemasukan - biaya & & \\
\hline R/C Ratio & & \\
\hline
\end{tabular}

Tabel 3. Rata-rata tingkat pengetahuan, sikap dan keterampilan respoden

\begin{tabular}{lccccccc}
\hline \multirow{2}{*}{ Deskripsi } & \multirow{2}{*}{$\begin{array}{c}\text { Nilai } \\
\text { max }\end{array}$} & \multicolumn{3}{c}{ Nilai yang diperoleh } & \multicolumn{2}{c}{ Perubahan } \\
\cline { 3 - 8 } & & E. Awal & $\%$ & E. Akhir & $\%$ & Nilai & $\%$ \\
\hline Pengetahuan & 375 & 178 & 47.5 & 278 & 74.1 & 100 & 26.7 \\
Keterampilan & 375 & 163 & 43.5 & 274 & 73.1 & 111 & 29.6 \\
Sikap & 375 & 160 & 42.7 & 278 & 74.1 & 118 & 31.5 \\
\hline
\end{tabular}

Tabel 3. Rata-rata dan selisih perubahan tingkat pengetahuan, sikap dan keterampilan responden

\begin{tabular}{llccc}
\hline Parameter & Jumlah responden & 25 & Rata-rata & Selisih \\
\hline \multirow{3}{*}{ Pengetahuan } & Tes awal & 178 & 7,12 & $-4,00$ \\
& Tes akhir & 278 & 11,12 & \\
& $\mathrm{D}$ & 100 & & \\
& $\mathrm{D}^{2}$ & 10000 & & $-4,36$ \\
Keterampilan & Tes awal & 163 & 6,6 & \\
& Tes akhir & 274 & 10,96 & $-4,72$ \\
& $\mathrm{D}$ & 111 & & \\
\multirow{3}{*}{ Sikap } & $\mathrm{D}^{2}$ & 1232 & & \\
& Tes awal & 160 & 6,40 & \\
& Tes akhir & 278 & 11,12 & \\
\hline & $\mathrm{D}^{2}$ & 118 & & \\
\hline
\end{tabular}

Keterangan: $\mathrm{n}=$ Jumlah Responden, $\mathrm{d}=$ Perbedaan nilai antara pasangan, $\mathrm{d}^{2}=$ Kuadrat perbedaan nilai antara pasangan. 


\section{Penyuluhan}

Tabel 3 menunjukkan bahwa tingkat perubahan tertinggi terjadi pada sikap responden yaitu 31,5\%, selanjutnya perubahan keterampilan yaitu 29,6\% dan tingkat perubahan pengetahuan yaitu sebesar $26,7 \%$. Tabel 3 menunjukkan bahwa nilai perbedaan rata-rata dan selisih pasangan sampel / responden pada tingkat pengetahuan yaitu $-4,00$, pada tingkat keterampilan -4,36 dan pada tingkat sikap -4,72.

Hasil evaluasi awal dan akhir tingkat pengetahuan, keterampilan dan sikap diuji menggunakan SPSS versi 16. Hasil uji Dependen Sample T-Test untuk tingkat pengetahuan dengan nilai signifikan $0.00<0,05$, pada tingkat sikap diperoleh nilai signifikan 0,00 $<0,05$ dan tingkat keterampilan diperoleh nilai signifikan $0.00<0.05$. Hal ini menyatakan evaluasi menunjukkan perbedaan pengetahuan, sikap dan keterampilan pada evaluasi awal dan hasil evaluasi akhir. Evaluasi penyuluhan dihitung dengan menggunakan rumus Ginting (1991).

\section{KESIMPULAN}

1. Pemberian tepung daun indigofera dalam taraf 5\% dapat direkomendasikan untuk diaplikasikan pada ayam broiler;

2. Berdasarkan analisis R/C Rasio diketahui bahwa pemanfaatan tepung daun indigofera layak untuk dikembangkan;

3. Hasil evaluasi penyuluhan memperlihatkan perubahan yang nyata sebelum dan setelah pelaksanaan penyuluhan.

\section{DAFTAR PUSTAKA}

Anggorodi. 1980. Ilmu Makanan Ternak Umum. Jakarta, PT. Gramedia
Fadilah, R. 2005. Panduan Mengelola Peternakan Ayam Broiler Komersial. Cet-3.PT. Agro Media Pustaka: Jakarta.

Gaspersz, V. 1991. Metode Perancangan Percobaan. Penerbit Armico. Bandung.

Melia, A.S. 2017. Penggunaan Tepung Pucuk Indigofera Zollingeriana sebagai Pengganti Bungkil Kedelai dalam Ransum dan Pengaruhnya Terhadap Kesehatan Broiler. Jurnal Peternakan, Volume 1, Nomor 02, Halaman 21.

Palupi. R, Abdullah. L, Astuti. D.A, Sumiati. 2014. Potensi dan Pemanfaatan Tepung Pucuk Indigofera $s p$. sebagai Bahan Pakan Subtitusi Bungkil Kedelai dalam Ransum Ayam Petelur. JITV. Volume 19, Nomor 3. Halaman 210.

Padmowihardjo, S. 2002. Evaluasi Penyuluhan Pertanian, Pusat Penelitian Universitas Indonesia. Depdiknas, Jakarta.

Parakassi, A. 1990. Ilmu Gizi dan Makanan Ternak Monogastrik. Cetakan pertama. UIP: Jakarta.

Siregar, A. P. 1980. Teknik Beternak Ayam Pedaging di Indonesia. Merdie Group: Jakarta.

Sofjan, O. dan Surisdiarto, H., 2003. Penggantian Jagung kuning dengan tepung gaplek dalam pakan ayam pedaging yang menggunakan konsentrat. Anim. Prod. 5 (4):7-13.

Wiradisastra, M.D.H. 1986. Efektivitas Keseimbangan Energi dan Asam Amino dan Efisiensi Absorpsi dalam Menentukan Persyaratan Kecepatan Tumbuh Ayam Broiler. Bogor. Disertasi, Institut Pertanian Bogor. 